九州大学学術情報リポジトリ

Kyushu University Institutional Repository

\title{
Evaluation of Fluorogenic Assay for the Rapid Detection of Salmonella in Foods
}

Mi yamoto, Takah isa

Laboratory of Food Hygienic Chemistry, Faculty of Agriculture, Kyushu University

Tamai, Rumiko

Laboratory of Food Hygienic Chemistry, Faculty of Agriculture, Kyushu University

Ze, Tian Hue

Laboratory of Food Hygienic Chemistry, Faculty of Agriculture, Kyushu University

Yoshimoto, Makoto

Laboratory of Food Hygienic Chemistry, Faculty of Agriculture, Kyushu University

他

https://doi.org/10.5109/24036

出版情報: 九州大学大学院農学研究院紀要. 38 (1/2)，pp.47-54，1993-12. Kyushu University バージョン：

権利関係: 
J. Fac. Agr., Kyushu Univ., 38(1•2), 47-54 (1993)

\title{
Evaluation of F luorogenic Assay for the R apid Detection of Salmonella in Foods
}

\author{
Takahisa Miyamoto, Rumiko Tamai, Tian Hue Ze, \\ Makoto Yoshimoto and Shoji Hatano \\ Laboratory of Food Hygienic Chemistry, Faculty of Agriculture, \\ Kyushu University 46-09, Fukuoka 812, Japan \\ (Received May 28, 1993)
}

\begin{abstract}
A fluorogenic assay for rapid detection of Salmonella was evaluated in various foods. The assay involves an enrichment culture of Salmonella in Dulcitol-Malachite greenNovobiocin medium $\left(0.5 \%\right.$ bactotryptone, $0.5 \%$ dulcitol, $0.16 \% \mathrm{KH}_{2} \mathrm{PO}_{4}, 0.8 \% \mathrm{NaCl}$, $4.0 \% \mathrm{MgCl}_{2} \cdot 6 \mathrm{H}_{2} \mathrm{O}, 0.01 \%$ malachite green, $1 / * \mathrm{~g} / \mathrm{ml}$ novobiocin, $\mathrm{pH} 5.0$ ) for $22 \mathrm{hr}$ at $30^{\circ} \mathrm{C}$ with shaking. After the cultivation, alanine-arylamidase activity of the bacteria was measured by fluorescence using the fluorogenic substrate alanine-7-aminomethylcoumarin. Forty two contaminated samples of 7 foods were examined for Salmonella by the fluorogenic assay. The results were then compared with those obtained by the conventional Deoxycholate-Hydrogen sulfide-Lactose agar plating assay. In the case of raw chicken, raw pork, autoclaved pork and frozen hamburg, Salmonella-cell number and the activity was correlated. The correlation coefficient was 0.77 . However, the sensitivity of the assay was lower in samples such as raw egg, eggroll and smoked pork ham than in samples described above. The low sensitivity in raw egg seems to be caused by its low concentration of nutrients essential for the growth of Salmonella, but not by growth inhibitors such as lysozyme and conalbumin present in it. The present assay can detect $10 \mathrm{CFU}$ of Salmonella per gram of sample after a $24 \mathrm{hr}$-total-detection time though the application of this assay is limited to several kinds of foods.
\end{abstract}

\section{INTRODUCTION}

Among foodborne diseases took place in Japan, about 15\% are salmonellosis (Ito and Yunokawa, 1990). Most of the salmonellosis is caused by meat and meat product. Conventional Salmonella detection from foods requires a minimum of 4 day after sample receipt to obtain presumptive results (Ito et al., 1980). Because of the growing needs of the food industry and government agencies for more rapid and simple Salmonella detection methods, some of the novel techniques have been developed (Konuma, 1989). The fluorogenic assay, using a fluorogenic substrate for the highsensitivity detection of an enhanced enzymatic activity in bacteria, is one of these methods (Bascomb, 1987; Miyamoto et al., 1989 and 1990). We have reported that Salmonella has a relatively high alanine-arylamidase activity that can be used as a marker enzyme for detection of the bacteria (Miyamoto et al., 1991). Although a high arylamidase activity of raw foods interfered with the measurement of Salmonella arylamidase activity, the interference was remarkably reduced by measuring the activity at $\mathrm{pH}$ 9.5. We have also developed a selective medium of Salmonella for effective detection of the enzyme activity of the bacteria (Miyamoto et al., 1991).

The aim of this study was to evaluate the efficacy of the fluorogenic assay in detecting Salmonella from contaminated foods and to elucidate any problem that requires further study before practical use. 


\section{MATERIALS AND METHODS}

\section{Strains}

Salmonella typhimurium IFO 12529 and Escherichia coli IFO 3301 were purchased from the Institute for Fermentation, Osaka, Japan.

\section{Fluorogenic substrate}

Alanine-7-aminomethylcoumarin was obtained from Peptide Institute, Inc., Osaka, Japan. The fluorogenic substrate was dissolved in dimethyl sulfoxide at a concentration of $6 \mathrm{mM}$ and kept at $-20^{\circ} \mathrm{C}$.

\section{Media}

Dulcitol-Malachite green-Novobiocin (DMN) medium $(0.5 \%$ bactotryptone, $0.5 \%$ dulcitol, $0.16 \% \mathrm{KH}_{2} \mathrm{PO}_{4}, 0.8 \% \mathrm{NaCl}, 4.0 \% \mathrm{MgCl}_{2} \bullet 6 \mathrm{HzO}, 0.01 \%$ malachite green, $\mathrm{pH}$ 5.0) was prepared and heated in a boiling water for $30 \mathrm{~min}$. The medium was cooled rapidly in a cold water after heating. A solution of novobiocin, sterilized with a membrane filter, was added at a final concentration of $1 \mu \mathrm{g} / \mathrm{ml}$ after cooling the medium. Enterobacteriaceae-Enrichment Mannitol (EEM) broth and DeoxycholateHydrogen sulfide-Lactose (DHL) agar were purchased from Eiken Chemical Co., Ltd., Tokyo, Japan. Selenite broth, Triple-Sugar-Iron (TSI) agar and Lysine-Indole-Motility (LIM) medium were obtained from Nissui Pharmaceutical Co., Ltd., Tokyo, Japan.

\section{Preparation of food samples}

Commercial foods, listed in Table 1, which had been confirmed to be free from Salmonella were used in this study. These foods were artificially contaminated with $S$. typhimurium IFO 12529 at various cell numbers. Raw egg was also contaminated with E. coli IFO 3301 from $10{ }^{3}$ to $10^{5} \mathrm{CFU} / \mathrm{g}$. Ten grams of each food was homogenized in $90 \mathrm{ml}$ of sterile saline with a sterile Waring Blender at 14,700 rpm for 2 min and used as a sample homogenate. To investigate the effects of whole egg, egg yolk, and egg white on the growth of Salmonella, they were homogenized with Waring Blender and then diluted with sterile saline.

\section{Conventional detection of Salmonella and other enteric bacteria}

Food samples were at first tested for the presence of Salmonella by a standard cultural method. Briefly, $25 \mathrm{~g}$ of the samples was homogenized in $225 \mathrm{ml}$ of EEM broth and then preenriched by incubation for $16 \mathrm{hr}$ at $37^{\circ} \mathrm{C}$. Preenrichment was followed by selective enrichment in selenite broth which was incubated for $24 \mathrm{hr}$ at 43 "C. Streaking on selective agar medium was done on DHL agar. Suspect colonies were picked up and Salmonella was confirmed by the following biochemical tests: gas production from glucose and hydrogen sulfide production in TSI agar; decarboxylation of lysine, indole production and motility in LIM medium.

Numbers of Salmonella inoculated and other enteric bacteria in food samples were counted in the following manner. After the sample homogenate was lo-fold serially diluted with sterile saline, $0.1 \mathrm{ml}$ of the diluted sample was then spread over DHL agar. After incubation at $35^{\circ} \mathrm{C}$ for $18 \mathrm{hr}$, the colonies formed were counted. The lower limit of detection of the plating assay is $100 \mathrm{CFU}$ per gram. 


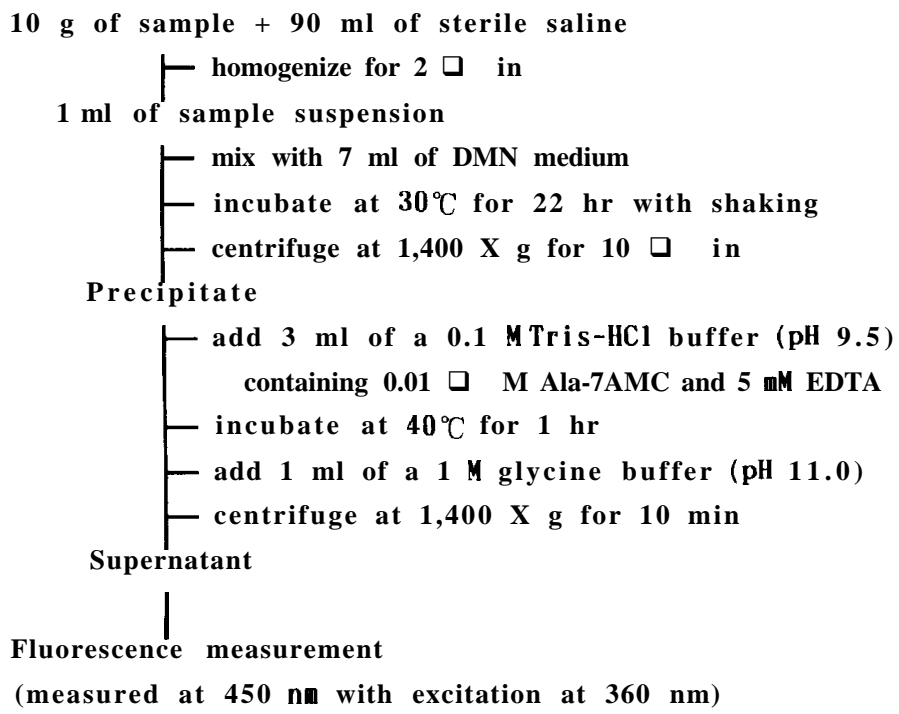

Fig. 1. Procedure of fluorogenic assay for detection of Salmonella in foods.

\section{Procedure of fluorogenic assay for rapid Salmonella detection}

Procedure of fluorogenic Salmonella detection is shown in Fig. 1. One mililiter of sample homogenate was added to a test tube containing $7 \mathrm{ml}$ of DMN medium. The mixture was cultured for $22 \mathrm{hr}$ at $30^{\circ} \mathrm{C}$ with shaking. After centrifugation at $1,400 \times \mathrm{g}$ for $10 \mathrm{~min}$, alanine-arylamidase activity of the precipitate was measured. To the precipitate, $3 \mathrm{ml}$ of a $0.1 \mathrm{M}$ Tris- $\mathrm{HCl}$ buffer ( $\mathrm{pH}$ 9.5) including $\mathrm{O} . \mathrm{OlmM}$ alanine-7. aminomethylcoumarin and $5 \mathrm{mM}$ ethylenediaminetetraacetic acid (EDTA) was added and these were allowed to react at $40{ }^{\circ} \mathrm{C}$ for $1 \mathrm{hr}$. The reaction was stopped by adding $1 \mathrm{ml}$ of $1 \mathrm{M}$ glycine buffer $(\mathrm{pH} 11.0)$, then the reaction mixture was centrifuged at 1,400 $\boldsymbol{x} \boldsymbol{g}$ for $10 \mathrm{~min}$, and the supernatant was used to measure the fluorescence intensity with an Ajinomoto fluorospectrometer, FLUOROREAD Model 200. The excitation wavelength was $360 \mathrm{~nm}$ and fluorescence intensity was measured at $450 \mathrm{~nm}$. As a control, the culture medium without bacterial cells and sample homogenate was similarly assayed. The enzyme activity was expressed as the fluorescence intensity of the test sample relative to that to the control sample set at 50 .

\section{RESULTS}

\section{Detection of Salmonella from various foods by fluorogenic assay}

The detection of Salmonella in commercial foods was made by the fluorogenic assay and conventional assay. Forty three artificially contaminated samples of 7 foods were examined for Salmonella by the fluorogenic assay. The results were compared with those obtaind by the conventional assay (Table 1). Figure 2 shows the relationship between the cell numbers of S. typhimurium in foods and alanine-arylamidase activities 
Table 1. Detection of Salmonella in food by fluorogenic assay and conventional plating assay.

\begin{tabular}{|c|c|c|c|}
\hline Sample & $\begin{array}{l}\text { Salmonella } \\
(\mathrm{CFU} / \mathrm{g})^{\mathrm{a}}\end{array}$ & $\begin{array}{c}\text { Enteric } \\
\text { bacteria } \\
\text { except } \\
\text { Salmonella } \\
(\mathrm{CFU} / \mathrm{g})^{\mathrm{a}}\end{array}$ & $\begin{array}{c}\text { Alanine- } \\
\text { arylamidase } \\
\text { activity } \\
\text { (fluorogenic } \\
\text { assay) }\end{array}$ \\
\hline Control & 0 & 0 & 1.0 \\
\hline \multirow[t]{6}{*}{ Raw pork } & 0 & $1.0 \times 10^{4}$ & 1.5 \\
\hline & $1.5 \times 10^{1}$ & $1.1 \times 10^{4}$ & 4.2 \\
\hline & $1.5 \times 16$ & $1.3 \times 10^{4}$ & 5.0 \\
\hline & $1.6 \times 10^{3}$ & $1.4 \times 10^{4}$ & 30.6 \\
\hline & $1.4 \times 10^{4}$ & $1.2 \times 10^{4}$ & 48.8 \\
\hline & $1.5 \times 10^{6}$ & $1.2 \times 10^{4}$ & 46.3 \\
\hline \multirow[t]{6}{*}{ Raw chicken } & 0 & $3.1 \times 10^{4}$ & 1.4 \\
\hline & $5.1 \times 10^{0}$ & $3.3 \times 10^{4}$ & 4.4 \\
\hline & $5.1 \times 10^{1}$ & $3.2 \times 10^{4}$ & 4.4 \\
\hline & $6.0 \times 10^{2}$ & $3.3 \times 10^{4}$ & 8.4 \\
\hline & $4.2 \times 16$ & $3.2 \times 10^{4}$ & 16.5 \\
\hline & $5.1 \times 10^{5}$ & $3.1 \times 10^{4}$ & 31.3 \\
\hline \multirow[t]{8}{*}{ Raw egg ${ }^{b}$} & 0 & $2.2 \times 10^{3}$ & 1.0 \\
\hline & $5.0 \times 16$ & $2.6 \times 16$ & 1.0 \\
\hline & $3.3 \times 10^{3}$ & $3.0 \times 10^{3}$ & 1.0 \\
\hline & $3.3 \times 10^{3}$ & $2.1 \times 10^{5}$ & 1.2 \\
\hline & $3.3 \times 10^{4}$ & $2.1 \times 10^{5}$ & 2.0 \\
\hline & $3.3 \times 10^{4}$ & $3.0 \times 10^{3}$ & 2.3 \\
\hline & $3.3 \times 10^{5}$ & $2.1 \times 10^{5}$ & 6.9 \\
\hline & $3.3 \times 10^{5}$ & $3.0 \times 16$ & 8.0 \\
\hline \multirow[t]{7}{*}{ Autoclaved pork } & 0 & $<1.0 \times 10^{2}$ & 1.0 \\
\hline & $1.0 \times 10^{1}$ & $<1.0 \times 10^{2}$ & 1.0 \\
\hline & $9.0 \times 10^{1}$ & $<1.0 \times 10^{2}$ & 2.2 \\
\hline & $6.4 \times 10^{2}$ & $<1.0 \times 10^{2}$ & 5.1 \\
\hline & $6.0 \times 10^{3}$ & $<1.0 \times 10^{2}$ & 8.9 \\
\hline & $7.1 \times 10^{4}$ & $<1.0 \times 10^{2}$ & 12.6 \\
\hline & $7.1 \times 10^{5}$ & $<1.0 \times 10^{2}$ & 17.0 \\
\hline \multirow[t]{5}{*}{ Eggroll } & 0 & $<1.0 \times 10^{2}$ & 1.0 \\
\hline & $3.4 \times 10^{2}$ & $<1.0 \times 10^{2}$ & 1.1 \\
\hline & $3.8 \times 16$ & $<1.0 \times 10^{2}$ & 1.2 \\
\hline & $3.4 \times 10^{4}$ & $<1.0 \times 10^{2}$ & 3.3 \\
\hline & $3.4 \times 10^{5}$ & $<1.0 \times 10^{2}$ & 5.5 \\
\hline \multirow[t]{6}{*}{ Frozen hamburg } & 0 & $2.5 \times 10^{2}$ & 1.0 \\
\hline & $3.0 \times 10^{\prime}$ & $2.5 \times 10^{2}$ & 1.2 \\
\hline & $3.4 \times 10^{2}$ & $2.5 \times 10^{2}$ & 3.4 \\
\hline & $3.8 \times 10^{3}$ & $2.5 \times \mathrm{lb}$ & 6.4 \\
\hline & $3.4 \times 10^{4}$ & $2.5 \times 10^{2}$ & 10.6 \\
\hline & $3.4 \times 10^{5}$ & $2.5 \times 10^{2}$ & 14.6 \\
\hline \multirow[t]{5}{*}{ Smoked pork ham } & & $<1.0 \times 10^{2}$ & 1.0 \\
\hline & $3.4 \times 10^{2}$ & $<1.0 \times 10^{2}$ & 1.2 \\
\hline & $3.8 \times 10^{3}$ & $<1.0 \times 10^{2}$ & 2.1 \\
\hline & $3.4 \times 10^{4}$ & $<1.0 \times 10^{2}$ & 5.0 \\
\hline & $3.4 \times 10^{5}$ & $<1.0 \times 10^{2}$ & 9.7 \\
\hline
\end{tabular}

${ }^{a}$ Cell counts with DHL agar plating assay.

b Artificially contaminated with E. coli from 10 " to $10^{5} \mathrm{CFU} / \mathrm{g}$. 


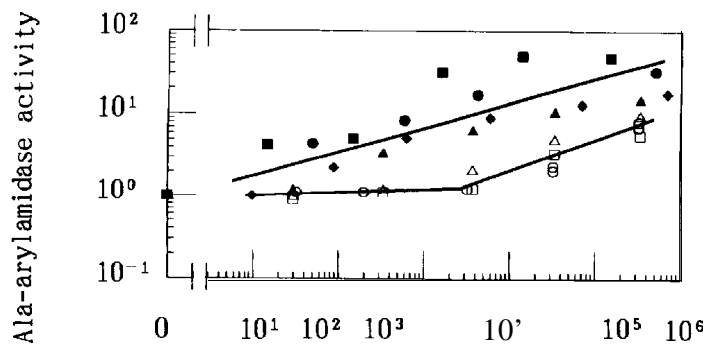

S. typhimurium in foods (CFU/g)

Fig. 2. Relationship between cell number of S. typhimuriumin foods and alaninearylamidase activity measured by the fluorogenic assay.

Alanine-arylamidase activities in foods including S. typhimurium and other enteric bacteria were measured by the fluorogenic assay. The cell numbers of S. typhimurium inoculated and other enteric bacteria in foods were measured by the DHL agar plating assay. Symbols: raw chicken; - , raw pork; A, frozen hamburg; $\bullet$, sterile pork; $\bigcirc$, raw egg contaminated with E.coli; $\square$, eggroll; $\triangle$, smoked pork ham.

measured by the fluorogenic assay.

Raw pork was naturally contaminated with about $10^{4} \mathrm{CFU}$ of enteric bacteria per gram. In spite of the presence of these enteric bacteria, S. typhimurium was detected over $15 \mathrm{CFU} / \mathrm{g}$ by the fluorogenic assay. Although raw chicken was also contaminated with about $10^{4} \mathrm{CFU}$ of enteric bacteria per gram, S.typhimurium could be detected over $5 \mathrm{CFU} / \mathrm{g}$ by the fluorogenic assay. In the case of autoclaved pork (a typical food free from microbial contamination), S.typhimurium was detected over $90 \mathrm{CFU} / \mathrm{g}$. In frozen hamburg, S. typhimurium was detected over $30 \mathrm{CFU} / \mathrm{g}$ even in the presence of $2.5 \times 10^{2}$ $\mathrm{CFU}$ of other enteric bacteria per gram. In the case of raw pork, raw chicken, autoclaved pork and frozen hamburg, the arylamidase activity was in proportion to the initial-S. typhimurium-cell number in them, no matter how many other bacteria were present (Table 1). S. typhimurium-cell number and alanine-arylamidase activity are correlated in these cases. The correlation coefficient was 0.77 . The assay can detect about $30 \mathrm{CFU}$ of Salmonella per gram of these samples after a $24 \mathrm{hr}$-total-detection time.

However, the sensitivity of the assay was lower in samples such as raw egg, egg-roll and pork ham than those in samples mentioned above. In raw egg, which was artificially contaminated with E.coli, S. typhimurium was detected over $33 \times 10^{4} \mathrm{CFU} /$ g. Lower limit of detection of the fluorogenic assay was about $10^{4}$ and $10^{3} \mathrm{CFU} / \mathrm{g}$ in eggroll and pork ham, respectively (Table 1).

\section{Effects of whole egg, egg yolk and egg white on growth and arylamidase activity of} Salmonella

Especially in raw egg and eggroll, the sensitivity of the fluorogenic assay was lower than that in raw chicken and pork. To clarify the reason of the low sensitivity in egg, alanine-arylamidase activity of S. typhimurium was measured after cultivation in DMN medium supplemented with homogenates of whole egg, egg yolk and egg white. Figure 


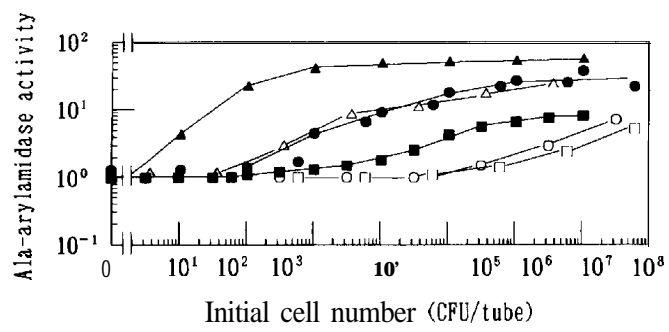

Fig. 3. Relationship between cell number and alanine-arylamidase activity of $\mathrm{S}$. typhimurium grown in the presence of whole egg, egg yolk and egg white.

Symbols: , 5 times diluted whole egg; $\quad 10$ times diluted whole egg; A, 5 times diluted egg yolk; $\triangle, 10$ times diluted egg yolk; $\bigcirc, 5$ times diluted egg white; $\square, 10$ times diluted egg white.

3 shows the effects of whole egg, egg yolk and egg white on alanine-arylamidase activity of S. typhimurium. When DMN medium was supplemented with egg yolk homogenate (5 times dilution), the arylamidase activity of S.typhimurium was detected at initial cell numbers over 10 . In contrast, the activity was detected at a initial cell number of $10^{5}$ when the medium was supplemented with egg white homogenate (5 times dilution). In both whole egg and egg yolk, the arylamidase activity of $\mathrm{S}$. typhimurium was lower in the presence of the homogenate of 10 times dilution than that of 5 times dilution. A similar relationship between cell number and the arylamidase activity was obtained by the cultivation in the presence of 5 times diluted whole egg and 10 times diluted egg yolk.

\section{E ffects of conalbumin and egg white lysozyme on fluorogenic detection of Salmonella}

It has been reported that conalbumin and lysozyme in egg white inhibit the growth of bacteria (Clark and Bueschkens, 1986). To examine if the low arylamidase activity of Salmonella grown in the presence of whole egg is due to the growth inhibition by conalbumin and lysozyme in egg white, the enzyme activity was measured after cultivation in DMN medium supplemented with egg yolk homogenate in the presence of conalbumin and/or lysozyme.

Figure 4 shows the relationship between initial cell number and alanine-arylamidase activity of S. typhimurium grown in DMN medium supplemented with egg yolk homogenate in the presence of conalbumin and/or lysozyme. The amounts of conalbumin and lysozyme included in $1 \mathrm{ml}$ of whole egg homogenate (10 times dilution) are $0.88 \mathrm{mg}$ and $0.32 \mathrm{mg}$, respectively. Conalbumin and/or lysozyme showed no effect on the arylamidase activity of S.typhimurium even if they were added at $8.8 \mathrm{mg}$ and 3.2 $\mathrm{mg}$, respectively. The result indicates that the bacterial growth inhibitors in egg white are not the major reason of the low sensitivity of the fluorogenic assay.

\section{DISCUSSION}

In the fluorogenic Salmonella detection from raw pork, raw chicken, autoclaved pork and frozen hamburg, the alanine-arylamidase activity of S. typhimurium increased 


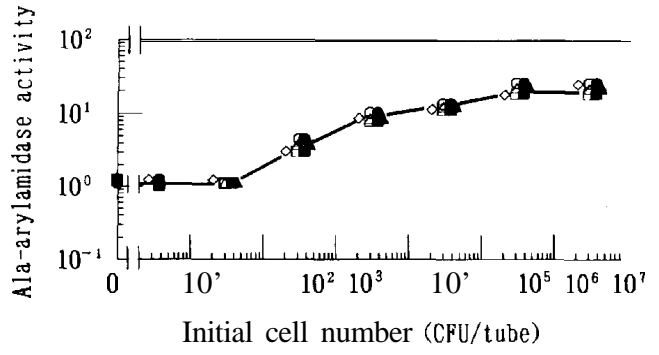

Fig. 4. Relationship between initial cell number and alanine-arylamidase acivity of S. typhimurium grown in the presence of conalbumin and/or lysozyme.

S. typhimurium was cultured in DMN medium mixed with egg yolk homogenate in the presence and absence of conalbumin and/or lysozyme. Alanine-arylamidase activity of $\mathrm{S}$. typhimurium was measured after the cultivation. Symbols; $\diamond$, Control (10 times diluted egg yolk); $\triangle, 0.88 \mathrm{mg}$ conalbumin; A, $8.8 \mathrm{mg}$ conalbumin; $\bigcirc, 0.32 \mathrm{mg}$ lysozyme;, $3.2 \mathrm{mg}$ lysozyme; $\square, 0.88 \mathrm{mg}$ conalbumin and $0.32 \mathrm{mg}$ lysozyme; $\mathbf{\square}, 8.8 \mathrm{mg}$ conalbumin and $3.2 \mathrm{mg}$ lysozyme.

with an increase in the initial cell number (Table 1 and Fig. 2). However, the arylamidase activity of S. typhimurium was low in the case of raw egg, eggroll and smoked pork ham (Table 1 and Fig. 2). Egg contains conalbumin and lysozyme and smoked pork ham contains various aldehydes and phenols that are inhibitory against the growth of various kinds of bacteria (Funatsu and Tsuru, 1977; Bacus, 1984). These substances in these foods were considered to inhibit the growth of S. typhimurium in DMN medium. In the case of raw egg, the arylamidase activity of S.typhimurium grown in the presence of egg white homogenate was lower than that in the presence of whole egg homogenate (Fig. 3). The effects of conalbumin and/or lysozyme on the growth of Salmonella was examined to clarify the reason of low sensitivity of the assay in egg. Clark and Bueschkens (1986) have reported that the viability of Campylobacter jejuni decreased with an increase in the incubation time with conalbumin and lysozyme. They used conalbumin at $13.8 \mathrm{mg} / \mathrm{ml}$ and lysozyme at $5 \mathrm{mg} / \mathrm{ml}$, the concentrations in native egg white, to test the lethal effects of these substances. In our experiment, $1 \mathrm{ml}$ of raw egg homogenate (10 times dilution) was mixed with $7 \mathrm{ml}$ of DMN medium. Since egg white comprises $65 \%$ of whole egg, DMN medium was supplemented with conalbumin and lysozyme at $0.88 \mathrm{mg}$ and $0.32 \mathrm{mg}$, respectively, to examine the effects of these substances on the growth of S. typhimurium. No effect of conalbumin and/or lysozyme on the arylamidase activity of S.typhimurium was observed at the concentrations (Fig. 4). The activity did not decrease even in the presence of both 8.8 $\mathrm{mg}$ of conalbumin and $3.2 \mathrm{mg}$ of lysozyme (Fig. 4). The result indicates that conalbumin and/or lysozyme have no effect on the growth of S. typhimurium. The cell number-arylamidase activity curve of S. typhimurium grown in DMN medium supplemented with lo-times diluted egg yolk was similar to that of S. typhimurium grown in the medium supplemented with 5-times diluted whole egg (Fig. 3). Taken together, these data indicate that in the case of raw egg and eggroll low sensitivity of the assay is probably attributed to low amount of nutrients essential for the growth of Salmonella. 
In DMN medium, malachite green and novobiocin are included to inhibit the growth of bacteria other than Salmonella. Concentrations of malachite green and novobiocin of the selective medium have been determined in the presence of raw pork homogenate (Miyamoto et al., 1991). Since constituents differ with different foods, it seems likely that the concentrations of these inhibitors are not suitable for the growth of Salmonella in DMN medium mixed with food homogenates such as raw egg and smoked pork ham. It is necessary to improve the selective medium and the method of sample preparation to decrease the difference of sensitivity of detection between foods to be tested.

The procedure of the fluorogenic assay including sample preparation, the selective medium and cultural conditions will be improved and reported shortly.

\section{REFERENCES}

Bacus, J. 1984 Utilization of Microorganisms in meat processing, a hand book for meat plant operators. Research Studies Press, London, (England)

Bascomb, S. 1987 Enzyme tests in bacterial identification. Methods Microbiol., 19: 105-160.

Clark, A. G. and D. H. Bueschkens 1986 Survival and growth of Campylobacter jejuni in egg yolk and albumen. J. Food Protection, 49 (2): 135-141.

Funatsu, M. and D. Tsuru 1977 Youkin-Kouso, Kohdansha Publishing Co., Ltd., Tokyo (Japan), pp. 227-244.

Ito, K. and T. Yunokawa 1990 The epidemiological data of food poisoning in 1989., Food Sanit. Res., 40: $90-124$.

Ito, T., T. Kawabata, H. Kurata, H. Kurisu, N. Minamikumo and M. Matsumoto 1980 Methods for the Microbiological Examination. In "Standard methods of analysis for hygienic chemists -with commentary-" ed. by Pharm. Soc., Jpn., Kanahara Publishing Co., Tokyo (Japan), pp. $102-129$.

Konuma, H. 1989 Rapid method and automation in food microbiological examination. Food Sanit. Res., 39: 39-53.

Miyamoto, T., Y. Sheu, H. Miwa and S. Hatano 1989 A fluorogenic assay for the rapid detection of some V. parahaemolyticus in foods. J. Food Hyg. Soc., Jpn., 30 (6): 534-541.

Miyamoto, T., H. Miwa and S. Hatano 1990 Improved fluorogenic assay for rapid detection of V. parahaemolyticus in foods. Appl. Environ. Microbiol., 56: 1480-1484.

Miyamoto, T., K. Yonemura, M. yoshimoto, Y. Morinaga and S. Hatano 1991 Rapid detection of Salmonella by fluorogenic assay. Jpn. J. Food Microbiol., 8 (3):143-150. 